\author{
AGNIESZKA LATOS \\ (iD https://orcid.org/0000-0002-2549-3839 \\ Uniwersytet Humanistycznospołeczny SWPS \\ Warszawa
}

\title{
Feminatywy w stanowiskach Rady Języka Polskiego. Język a ewolucja normy społecznej*
}

Feminine forms in two statements of positions of the Polish Language Council.

Language and the evolution of the social norm

\begin{abstract}
The paper attempts to reflect on the evolution of the social norm and on linguistic and codification-related changes with regard to feminine personal nouns. The main aim is to posit and reflect on the problem of feminine forms in contemporary Polish on the basis of a critical comparison of opinions on their creation and use formulated by the Polish Language Council, a body issuing opinions and giving advice on the use of the Polish language. The significant differences in positions taken by scientists over the course of just a few years suggest that the issue of feminine forms was and continues to be to a large extent an element of the sociopolitical debate with an ideological, social and emotional tinge, rather than an issue resulting from the actual limitations of the language system.
\end{abstract}

Keywords: personal nouns, feminine forms, linguistic norm, Polish language, Polish Language Council

\section{Wstęp}

Publiczna debata na temat feminatywów (tj. żeńskich form osobowych) w języku polskim nie traci na aktualności, mimo iż trwa od kilkudziesięciu lat. Polemika, systematycznie rozbudzana publicznymi wystapieniami i konfrontacjami, charakteryzuje się silnym zabarwieniem ideologicznym i zaangażowaniem emocjonalnym. W dyskusji, prowadzonej głównie na łamach polskich mediów publicznych oraz w mediach społecznościowych, polary-

\footnotetext{
* Autorka dziękuje za cenne sugestie Aleksandrze Pronińskiej oraz anonimowym recenzentom.
} 
zują się dwie tradycyjnie przeciwstawne pozycje dotyczące potrzeby, lub też jej braku, symetrycznego użycia nazw osobowych męskich i żeńskich. Ta trwająca nieprzerwanie społeczna debata nad feminatywami jest śledzona z zainteresowaniem i uwaga przez użytkowników języka polskiego ${ }^{1}$. Wieloletnia dyskusja przyczynia się, z jednej strony, do podejmowania różnorodnych badań teoretyczno-empirycznych w celu naukowego opisu zjawisk językowych związanych z zagadnieniem feminatywów ${ }^{2}$, a z drugiej, owocuje wzrostem świadomości na temat feminatywów wśród użytkowników języka. W ostatnich latach obserwuje się zwiększoną skłonność do tworzenia i stosowania osobowych form żeńskich w języku polskim (zob. Grochowska, Wierzbicka 2015; Sosnowski, Satoła-Staśkowiak 2019), mimo iż tendencja ta nierzadko traktowana jest jako przejaw nowomowy feministycznej (Krawczyk 2019). Od pewnego czasu w polszczyźnie zauważyć można również zjawisko oscylacji w doborze form osobowych określających kobietę, które wynika z równoczesnego stosowania przeciwstawnych wzorców użycia językowego (zob. Nowosad-Bakalarczyk 2009; Miodek 2010; Bralczyk 2014; Komander 2017).

Refleksja nad kodyfikacją językowa, tj. procesem formalnego kształtowania normy językowej, i charakterem zmian językowych w kierunku pełnej symetrii leksykalnej w obszarze nazw osobowych wydaje się szczególnie istotna z kilku powodów. Jeżeli o kształcie normy powinno decydować kryterium powszechności, oparte na danych statystycznych i frekwencyjnych (Wiśniewiecka-Brückner 2016, 192), to konieczna jest systematyczna aktualizacja wzorców w oparciu o wyniki badań nad ewolucją zjawisk językowych, szczególnie jeśli zmiany w języku zachodzą dynamicznie (Żmigrodzki 2015). Brak kodyfikacji oraz dostępu do rzetelnych informacji na temat nowych, alternatywnych wariantów lub wzorców użycia może oddziaływać hamująco na stabilizowanie się pewnych modeli systemowych, które, choć wynikaja z potrzeby używania nowych środków językowych, nie znajduja jednak od-

${ }^{1}$ Ciekawym przykładem jest dyskusja na stronie otwartej grupy Tłumacze $i$ qlecenia dla ttumaczy w serwisie społecznościowym Facebooka zainicjowana 8 grudnia 2019 roku przez Danutę Przepiórkowską postem zatytułowanym Formy żeńskie - współczesna nowomowa? i ilustrującym niezwykle bogate użycie feminatywów w tekstach modlitw (litanie). W niespełna dwadzieścia cztery godziny post ten został skomentowany 54 razy i oznaczony jako interesujący przez 84 użytkowników grupy https://www.facebook.com/search/top/?q=Danuta \%20przepi\% C3\%B3rkowska\&epa=SEARCH_BOX [dostęp: 09.12.2019].

2 Niemożliwe jest wskazanie pełnego spisu prac ze względu na ich bardzo dużą liczbę. Obszerne analizy problematyki feminatywów zawarte są m.in. w następujących pracach: Łaziński 2006; Kubiszyn-Mędrala 2007; Grochowska, Wierzbicka 2015; Sosnowski i Satoła-Staśkowiak 2019. 
zwierciedlenia w uzusie, pojmowanym jako sposób realizacji werbalnych akceptowany wśród użytkowników języka (Markowski 2005).

Powołana do życia we wrześniu 1996 roku Rada Języka Polskiego, do której priorytetowych zadań należą między innymi:

upowszechnianie wiedzy o języku polskim, jego odmianach, normach i kryteriach oceny jego użycia oraz proponowanie form językowych odpowiednich w różnych sytuacjach [a także] rozstrzyganie wątpliwości językowych co do słownictwa, gramatyki, wymowy, ortografii i interpunkcji, a także co do stosowności stylistycznego kształtu wypowiedzi ${ }^{3}$

dwukrotnie zajęła oficjalne stanowisko dotyczące użycia feminatywów w języku polskim - po raz pierwszy stało się to 19 marca 2012 roku i po raz kolejny 25 listopada 2019 roku. Wyrażone w nich opinie są sprzeczne i stanowią świadectwo dynamicznej ewolucji poglądów na temat poprawności tworzenia i użycia żeńskich form osobowych we współczesnym języku polskim. Czynników sprawczych tej ewolucji należałoby dopatrywać się nie w zmianach wewnętrznojęzykowych, które musiałyby przecież zaistnieć na przestrzeni zaledwie kilku lat i zostać naukowo udokumentowane, lecz przede wszystkim w zmianach zewnętrznojęzykowych, wywołanych czynnikami o charakterze społeczno-politycznym i kulturowym, które związane sa z przemianami zachodzącymi w rzeczywistości pozajęzykowej. Hipoteza ta jest spójna z analizą Ostromęckiej-Frączak (2016, 82-83), według której na dzisiejszą polszczyznę najsilniej oddziałują czynniki zewnętrzne, które powoduja przewartościowania i głębokie transformacje, zauważalne szczególnie w obszarze leksyki.

Celem niniejszego artykułu jest krytyczna analiza oraz porównanie treści dwóch stanowisk Rady Języka Polskiego w sprawie feminatywów, a następnie wykazanie na podstawie przeprowadzonego porównania, iż problematyka użycia żeńskich form osobowych jest w przeważającej mierze elementem ideologicznej debaty o charakterze społeczno-politycznym, kulturowym i emocjonalnym, a nie problemem wynikającym z ograniczeń stricte językowych. Warto zauważyć, że budowa gramatyczna oraz zasoby leksykalne i procesy słowotwórcze języka polskiego implikują zwyczaj kodowania informacji o płci desygnatu wypowiedzi w sytuacjach komunikacyjnych,

\footnotetext{
3 Internetowa strona Rady Języka Polskiego, zakładka Podstawowe Informacje o Radzie, http:// www.rjp.pan.pl $/$ index.php?option $=$ com_content\&view $=$ article\&id $=212 \&$ Itemid $=7 \quad$ [dostęp: 02.12.2019].
} 
w których informacja ta jest poznawczo istotna oraz formalnie i pragmatycznie obligatoryjna (Latos 2019; 2018; Nowosad-Bakalarczyk 2009).

Problematyzacja zagadnienia feminatywów (cz. 1 niniejszego opracowania) poprzedza krytyczny opis stanowiska w sprawie żeńskich form nazw zawodów i tytułów zajętego przez Radę Języka Polskiego po raz pierwszy w roku 2012 (cz. 2) i po raz drugi w roku 2019 (cz. 3). Konfrontacja dwóch opinii i wnioski płynące $z$ tego porównania, przedstawione w formie konkluzji (cz. 4), zamykają niniejszy artykuł.

\section{Feminatywy, czyli żeńskie nazwy osobowe}

Feminatywy to żeńskie nazwy osobowe, czyli formy językowe, których desygnatem jest kobieta. Natomiast nazwy osobowe to bardzo zróżnicowana pod względem semantycznym grupa wyrażeń językowych służących oznaczaniu (tj. desygnacji) istot ludzkich, a zatem grupa wyrażeń parafrazowalnych jako 'osoba, która + wykonuje, petni, należy do, doswiadcza, cechuje sie lub jest'. Ta semantycznie niejednorodna i niezwykle bogata grupa leksykalna obejmuje nazwy zawodów i profesji, nazwy stanowisk i pełnionych funkcji społecznych, nazwy tytułów zawodowych, naukowych oraz wojskowych, nazwy osób pełniących określone role lub wchodzących w pewne relacje z innymi osobami (w tym role wynikające ze związków rodzinnych, np. ojciec, chræestny i społecznych, np. sasiad, kolega), nazwy osób przynależących do określonych grup społecznych (np. nacjonalista, kibic, wierny), nazwy osób charakteryzujących się określonymi cechami fizycznymi i psychologicznymi (np. brunet, len̂), nazwy osób wykonujących określone czynności lub działania (np. szachista, aktymista). Dyskusja publiczna nad feminatywami, jak i opinie Rady w tej sprawie, ograniczone są do nazw zawodów i funkcji publicznych, charakteryzujących się prestiżem społecznym i utożsamianych tradycyjnie z domeną męska. Zawężenie to ukazuje socjologiczne podłoże problemu językowego, a mianowicie asymetrię wynikającą z odmiennej percepcji kobiety i mężczyzny jako aktorów świata publicznego i profesjonalnego (zob. Majka-Rostek i in. 2015).

Nazwy osobowe w języku polskim zróżnicowane sa zazwyczaj ${ }^{4}$ na formy męskie (maskulatywy) i żeńskie (feminatywy). Sygnalizowanie i językowe kodowanie informacji o płci osoby wiąże się z jednej strony z faktem, iż

${ }^{4} \mathrm{~W}$ języku polskim istnieje grupa nazw osobowych niezróżnicowanych pod względem płci, np. osoba, człowiek, postać, gmiazda 'metaforycznie o osobie bardzo znanej, celebryta'. 
w komunikacji językowej, która ma wyraźny charakter antropomorficzny (Tabakowska 2001), istoty ludzkie stanowią obiekty percepcyjnie i kognitywnie najistotniejsze, co teoretyzowane jest w literaturze specjalistycznej jako kontinuum żywotności (ang. animacy continuum) (np. Sasse 1993, 659; Dahl 2000, 100; Croft 2003, 130), a z drugiej strony, z tym, że płeć, odzwierciedlająca binarne i elementarne zróżnicowanie biologiczne użytkowników języka, jest jedną z najważniejszych - jeśli nie prymarną - cech osobowych (Dahl 2000).

Podobnie jak w innych jezzykach indoeuropejskich (Meillet 1908; Lehmann 1993; Luraghi 2006), zróżnicowanie form nazw osobowych pod względem rodzaju naturalnego (płci) opiera się w języku polskim na dwóch głównych mechanizmach ${ }^{5}$. Pierwszy mechanizm to dywersyfikacja leksykalna rdzeni, czyli tworzenie wyrazów niezwiązanych morfologicznie w celu językowego różnicowania istot płci żeńskiej i męskiej. Chodzi o rzeczowniki niederywowane, które obejmują zarówno nazwy pospolite, np. wuj/ciotka czy brat/siostra, jak i nazwy własne takie jak żeńskie i męskie imiona osób, np. Anna, Piotr.

Drugi, późniejszy w perspektywie diachronicznej mechanizm, to opozycja leksykalna płci oparta na zróżnicowaniu morfologicznym wyrazów w procesie derywacji lub kompozycji słowotwórczej. Bazę procesu derywacyjnego stanowić moga zarówno rzeczowniki podstawowe, czyli te niepodzielne słowotwórczo (pan $\rightarrow$ pani, pijak $\rightarrow$ pijaczka, Wiestaw $\rightarrow$ Wiestawa), jak i rzeczowniki złożone (krwiodawca $\rightarrow$ krwiodawczynn) oraz inne części mowy (np. dewerbalna derywacja feminatywów, Łaziński 2006). Rzadziej opisywanym procesem morfologicznym są złożenia, w których przynajmniej jeden element jest nośnikiem informacji o płci, niezależnie od faktu czy występuje on w opozycji leksykalnej, czy też nie, np. pan młody/pani młoda, pan domu/pani domu, kobieta pajak, babcia klozetowa, chtopiec na posytki, artysta malar. Ten mechanizm pozwala na kodowanie informacji o płci żeńskiej wtedy, gdy w języku nie ma feminatywu, uznawanego za formę poprawną gramatycznie oraz znaczeniowo lub stylistycznie równoważna, np. pani minister, pani profesor, kobieta żotnierz.

W rzeczywistości pozajęzykowej przez długi czas dominowała asymetria pozycji społecznej, zawodowej i publicznej kobiety w stosunku do pozycji

${ }^{5}$ Biorąc pod uwage kategorię rodzaju gramatycznego i mechanizm związku zgody występujący w języku polskim w obrębie frazy nominalnej oraz poza nią, opozycja semantyczna kobieta-meżçyzna może być kodowana językowo również na poziomie morfosyntaktycznym, np. ta/ten kaleka, jestem głodny/głodna (Latos 2019). 
mężczyzny. Asymetria ta dopiero w czasach współczesnych niwelowana jest przez stopniowe zmiany społeczne o charakterze równouprawnieniowym. Jej przejawem jest fakt, iż derywacja form żeńskich od form męskich była $\mathrm{i}$ jest nadal procesem częstszym niż derywacja o odwrotnym kierunku (np. wdowa $\rightarrow$ wdowiec, położna $\rightarrow$ położny, gwiazda filmowa $\rightarrow$ gwiazdor filmowy); a także fakt, iż powstawanie nazw żeńskich morfologicznie niezależnych od form męskich ogranicza się do ról utożsamianych jako wyłącznie lub typowo kobiece (np. przedszkolanka, niania, kosmetyczka). Z perspektywy historycznej tworzenie feminatywów w sposób systematyczny i coraz bardziej symetryczny w stosunku do maskulatywów wynika przede wszystkim ze zmian, które zaszły i nadal zachodzą w rzeczywistości pozajęzykowej', w szczególności na przestrzeni ostatnich dwóch wieków. Czynniki te moga być zgrupowane w następujący sposób: ewolucja roli i statusu społecznego kobiety, zmiana uwarunkowań społeczno-kulturowych, w tym wzrost świadomości płci, oraz - w czasach współczesnych - wieloletnie działania i inicjatywy polityczne na rzecz równouprawnienia kobiet ${ }^{7}$. Warto zwrócić uwagę na fakt, że usymetrycznianie słownictwa w obszarze nazw osobowych to proces wieloetapowy, który nie przebiega w sposób równomierny.

Równoległe tworzenie form żeńskich to tendencja, która utrzymywała się w języku polskim (Kubiszyn-Mędrala 2007) oraz w innych językach europejskich (np. w języku włoskim, Lepschy 1998) do połowy zeszłego wieku. Świadczą o tym również zasoby leksykalne słowników, które w pierwszej połowie dwudziestego wieku notowały więcej nazw żeńskich niż w drugiej połowie stulecia (Kubiszyn-Mędrala 2007).

W latach sześćdziesiątych i siedemdziesiątych zeszłego wieku symetria słowotwórcza została zaburzona poprzez upowszechniająca się normę językową mająca na celu neutralizację opozycji płciowej kodowanej leksykalnie w języku. Norma ta narzuca użycie formy męskiej, uznanej ad hoc za neutralną we wszystkich kontekstach, zarówno w odniesieniu do mężczyzn, jak i kobiet, szczególnie w przypadku nazw zawodów lub funkcji o znacznym prestiżu społecznym (Markowski, Jadacka 1999). Uzasadnienia dla normy maskulinizującej leksykalne zasoby języka polskiego należy doszukiwać się w ówczesnym kontekście polityczno-społecznym i kulturowym, w którym zjawiskom poprawności politycznej w kulturze i języku towarzyszy ideolo-

${ }^{6}$ Podstawą jest założenie o istnieniu potrzeby językowego nazywania obiektów i zjawisk obecnych w rzeczywistości pozajęzykowej.

${ }^{7} \mathrm{Na}$ przykład programy Unii Europejskiej na rzecz równouprawnienia płci na lata 20162019 (Latos 2018, 119-120). 
giczna gloryfikacja funkcji społecznej, uznawanej przez niektórych za prymarną również w obrębie komunikacji międzyludzkiej (Latos 2018). Zwolennikiem podporządkowania języka roli społecznej był między innymi wybitny językoznawca Witold Doroszewski, który stwierdza, że „sprawa płci ministra jest tak samo pozbawiona związku z jego funkcją społeczno-państwowa jak i kolor jego oczu" (Doroszewski 1954, 611). W dyskusji tej nie zabrakło przeciwników „społecznego zdominowania” kwestii językowych. Wśród nich był inny wybitny językoznawca i historyk języka polskiego, Zenon Klemensiewicz (1957), który uznał, że różnica płci jest nieodzowną częścią logiki języka, a zatem konieczne jest tworzenie form żeńskich odzwierciedlających na przykład prawo kobiet do edukacji na poziomie uniwersyteckim oraz osiągane przez nie tytuły naukowe. Tę rozbieżność ideologiczną można uznać za podstawę wyrażanych do dzisiaj przeciwstawnych opinii na temat użycia feminatywów w języku polskim i wieloletniej publicznej debaty społecznej toczącej się na ten temat głównie na łamach mediów. Tworzenie feminatywów, wynikające z potrzeby adekwatnego określania kobiet pełniących dzisiaj coraz częściej funkcje czy zawody typowo 'męskie', nadal rozpatrywane jest w kontekście ruchów feministycznych i wiązane z ideologia płci ${ }^{8}$ (Scheller-Boltz 2017). Należy dodać, iż kobiety w pewnym sensie przyczyniły się do upowszechnienia watpliwej w swym zadaniu oraz uzasadnieniu neutralizującej normy językowej9, uznając formy męskie za bardziej prestiżowe i nobilitujące oraz wybierając je ze względu na presję społeczną w celu pokazania, że potrafią one pełnić funkcje i zawody wykonywane wcześniej tylko przez mężczyzn (Małocha-Krupa 2015).

Od lat dziewięćdziesiątych można zaobserwować wzrastającą tendencję do symetrycznego używania feminatywów, zarówno poprzez powrót do wcześniej powstałych form żeńskich, jak i przez tworzenie nowych form, w tym neologizmów i zapożyczeń, głównie z języka angielskiego, np. blogerka, freelancerka (Małocha-Krupa 2015). Ciąły wzrost aktywności zawodowej i publicznej kobiet powoduje, że językowa potrzeba nazywania wykonywanych przez nie zawodów i pełnionych ról czy funkcji oraz tytułowania ich w komunikacji bezpośredniej jest coraz silniejsza. Istotna w perspektywie społecz-

8 „Ideologie płci odnoszą się do wyobrażenia tego, w jaki sposób płeć, względnie jej tożsamość, jest kategoryzowana i hierarchizowana w społeczeństwie. Tego rodzaju przeświadczenia bazuja przede wszystkim na stereotypach (...). Ponadto ideologiczne wyobrażenia płci opierają się na konwencjach, które obowiązują w określonej wspólnocie (...)” (Scheller-Boltz 2017, 166).

${ }^{9}$ Jej rezultatem jest niegramatyczna w polskim systemie językowym nieodmienność fleksyjna form męskich wtedy, kiedy są one używane w odniesieniu do kobiety. 
nej staje się też możliwość jednoznacznego dekodowania informacji o płci osoby, która jest desygnatem wypowiedzi, szczególnie jeśli informacja ta jest poznawczo lub pragmatycznie relewantna dla użytkownika języka (Latos 2018). Nie należy zapominać, że wzrostowi skłonności do równoległego użycia męskich i żeńskich form osobowych towarzyszy duża frekwencja form inherentnie męskich, które stosowane są w odniesieniu do kobiet zgodnie ze zwyczajowo utrwaloną normą językowa. Istnienie przeciwstawnych wzorców językowych powoduje oscylację w doborze form osobowych określających kobiety, zarówno na płaszczyźnie zawodowej, np. Kinga W., wicedyrektor, nauczyciel dyplomowany, absolwentka UMCS, nauczycielka edukacji wczesnoszkolnej, jak i prywatnej, np. matka, żona, prayjaciel (zob. np. Nowosad-Bakalarczyk 2009).

\section{Stanowisko Rady Języka Polskiego z 2012 roku}

W marcu 2012 roku Rada Języka Polskiego zajęła po raz pierwszy stanowisko w sprawie żeńskich form nazw zawodów i tytułów ${ }^{10}$. Jak oficjalnie podano, stanowisko jest reakcja na publiczne wypowiedzi w mediach na temat formy nazw zawodów i prestiżowych funkcji publicznych zajmowanych przez kobiety. W opinii podkreśla się też fakt, że to właśnie kobiety zainicjowały nienową już debatę, opowiadając się za konsekwentnym i symetrycznym stosowaniem żeńskich i męskich form nazw stanowisk i zawodów. Rada przyznaje, iż niektóre propozycje nazw żeńskich są systemowo dopuszczalne i funkcjonują już w języku potocznym. Następnie wskazuje niektóre sufiksy słowotwórcze $\left(-k_{a},-i n i /-y n i,-a\right)$ umożliwiające tworzenie form żeńskich od męskich w procesie derywacji. Podkreśla się fakt, że derywowanie form rzeczownikowych za pomoca przyrostka $-a^{11}$ nie jest procesem „tradycyjnym” w języku polskim, ale może wynikać z faktu, iż formy tworzone za pomoca przyrostka -ka maja zabarwienie potoczne lub konotację zdrobnienia, gdyż sufiks ten pełni też funkcję deminutywna. Jako wadę neologicznych formacji żeńskich tworzonych przy pomocy przyrostka -a, Rada

\footnotetext{
10 Dokument opublikowany na stronie internetowej Rady Języka Polskiego: http://www. rjp.pan.pl/index.php?option=com_content\&view =article\&id=1359:stanowisko-rady-jzyka-p olskiego-w-sprawie-eskich-form-nazw-zawodow-i-tytuow\&catid=109\&Itemid=81 [dostęp: 30 . 11.2019].

11 Sufiks - $a$ stanowi podstawę dla regularnie derywowanych nazw żeńskich, np. radn-y $\rightarrow$ radn-a, ksiegow-y $\rightarrow$ ksiegow-a, spóźnialsk-i $\rightarrow$ spóźnialsk-a, z których tylko nieliczne są nacechowane ekspresywnie, np. blondyn $\rightarrow$ blondyn-a.
} 
uznaje synonimię leksykalna, potencjalną konotację zgrubiałości oraz dwuznaczność złożeń grzecznościowych typu pani premiera ${ }^{12}$.

Rada nawiązuje do stanowiska językoznawców, którzy opisują zjawisko kodowania informacji o płci osoby w oparciu o związek zgody między rzeczownikiem, nadrzędnym elementem określanym, i podrzędnymi mu elementami określającymi go na poziomie morfosyntaktycznym. Dzięki zjawisku kongruencji formy inherentnie męskie 'selekcjonujące' podrzędne fleksyjne formy żeńskie w danym kontekście syntaktycznym, np. we frazie nominalnej, odczytywane są jako wykładniki płci żeńskiej. W stanowisku wskazuje się, że tworzenie opozycji typu ten/ta insynier ${ }^{13}$ w oparciu o zróżnicowanie schematów kongruencji morfosyntaktycznej między rzeczownikiem i elementami syntaktycznie od niego zależnymi znajduje wyraz w zjawisku nieodmienności fleksyjnej form męskich wtedy, gdy formy te użyte są w odniesieniu do kobiet. Niegramatyczne systemowo struktury są uznane za odpowiednie rozwiązanie językowe, które w pełni zaspakaja potrzebę komunikacyjnego sygnalizowania informacji o płci żeńskiej osoby będącej desygnatem wypowiedzi.

W konkluzji podkreśla się po raz kolejny, że formy żeńskie nazw zawodów i tytułów są systemowo dopuszczalne, natomiast powszechne ich niestosowanie wynika z negatywnych reakcji, jakie budzą wśród większości użytkowników języka. Możliwość zmiany tej sytuacji przez „przekonanie użytkowników języka polskiego o istotności użycia feminatywów, implikujących zawodowe i publiczne równouprawnienie kobiet”, zostaje odrzucona, ponieważ działanie takie byłoby „niespójne z logika języka, któremu nie da się narzucać wzorców użycia poprzez odgórne regulacje prawne”.

\section{Stanowisko Rady Języka Polskiego z 2019 roku}

Kolejna opinia w sprawie żeńskich form nazw zawodów i tytułów sformułowana została przez Radę Języka Polskiego w listopadzie 2019 roku ${ }^{14}$ w re-

\footnotetext{
12 Warto zauważyć, że w odróżnieniu od grzecznościowej formy adresatywnej pan minister, w złożeniu pani minister leksem pani jest jednocześnie formą honoryfikatywną i jedynym nośnikiem informacji o płci żeńskiej adresata wypowiedzi.

${ }^{13}$ Ich opis jako pary rzeczowników jest wysoce problematyczny w świetle ogólnie akceptowanych teorii językoznawczych na temat leksemów rzeczownikowych i zjawisk kongruencji morfosyntaktycznej w obrębie frazy nominalnej.

14 Dokument opublikowany na stronie internetowej Rady Języka Polskiego: http://www.
} 
akcji na nadal toczacą się debatę polityczno-społeczną na temat feminatywów. W ocenie Rady w dyskusji przeważają argumenty natury społecznej i ideologicznej, które nie są odróżniane of faktów stricte językowych. Zajęcie nowego stanowiska w sprawie feminatywów umotywowane zostaje faktem, iż od momentu wydania pierwszej opinii zaszły gruntowne zmiany w języku polskim i w świadomości społecznej.

Ilustrowane są dwie przeciwstawne tendencje, które zaobserwować można w języku polskim dwudziestego wieku, a mianowicie tendencja do symetrycznego i regularnego tworzenia niezależnych syntaktycznie żeńskich form osobowych oraz zwyczaj, który upowszechnił się w drugiej połowie dwudziestego wieku, i polega na sygnalizowaniu informacji o płci żeńskiej desygnatu ludzkiego albo przez użycie formy analitycznej złożonej z leksemu pa$n i$ i męskiej nazwy osobowej, albo przy wykorzystaniu zjawiska kongruencji morfosyntaktycznej. Obydwa rozwiązania to strategie uzupełniające lukę leksykalną wynikająca z braku powszechnie używanej syntetycznej formy żeńskiej. Podkreśla się fakt, iż od lat dziewięćdziesiątych zeszłego wieku pierwsza z tendencji zdaje się przeważać nad drugą.

Niezwykle istotnym stwierdzeniem jest, że „większość argumentów przeciw tworzeniu nazw żeńskich jest pozbawiona podstaw". W stanowisku porusza się przykładowo kwestie synonimiczności leksemów takich jak pilotka, zbitek spółgłoskowych w strukturze fonologicznej słów psycholożka czy antropolożk $a^{15}$, czy też wielofunkcyjności przyrostków. Proponuje się również wykorzystanie typowych sufiksów żeńskich -ini/-yni i -ka w miejsce nietypowych formacji słowotwórczych tworzonych przez zmianę końcówek fleksyjnych oraz przypomina się, że dominującym schematem dla żeńskich rzeczowników tytularnych są w dalszym ciagu konstrukcje analityczne z leksemem pani.

Symetria leksykalna w obszarze form osobowych nie może być rozstrzygana w odniesieniu do tradycji czy też reguł systemu językowego, gdyż jest ona silnie uwarunkowana społecznie, a zatem to użycie form żeńskich, zależne od wyborów dokonywanych przez użytkowników języka i uzależnione od ich specyficznych potrzeb komunikacyjnych, stanowi rozstrzygajacy argument w kwestii feminatywów. Przypomina się, iż medialnie nagłaśniana potrzeba dążenia do równoległego stosowania żeńskich i męskich nazw

rjp.pan.pl/?fbclid=IwAR1kv1H6JbQMirNpJ9v3ljow4zNISfIQsdsmTxrsdX9G91YhWzX6b HCL4EQ [dostęp: 02.12.2019].

${ }^{15}$ Formy te występują w Narodowym Korpusie Języka Polskiego (http://nkjp.pl/). 
osobowych napotyka opór części użytkowników, którzy nie są skłonni do stosowania nowych form żeńskich i mają do tego prawo. Jednocześnie stwierdza się, że zadaniem językoznawców jest śledzenie i opis użyć językowych oraz wynikających z nich zmian w obrębie systemu językowego.

Finalnie Rada uznaje potrzebę usymetryczniania zasobów słownictwa i zachęca do używania żeńskich i męskich form osobowych w sposób równoległy, a jednocześnie wyjaśnia, iż symetryczność konstrukcji typu Polacy i Polki nie jest zawsze konieczna, gdyż w języku stosuje się również formy męskie, które w odpowiednich kontekstach dyskursu mogą odnosić się do obu płci.

\section{Porównanie stanowisk i konkluzje}

Z perspektywy językoznawstwa wewnętrznego pierwszą opinię Rady charakteryzuje szereg problemów teoretycznych, które wynikają z braku uznania wielofunkcyjności elementów gramatycznych takich, jak sufiksy słowotwórcze czy też powszechności i uniwersalności zjawiska synonimiczności leksemów w jezzykach naturalnych. Złożona problematyka asymetrii leksykalnych w obszarze nazw osobowych we współczesnej polszczyźnie ilustrowana jest w sposób teoretycznie niespójny. Problematyczne jest nierozróżnienie formalnych aspektów budowy języka od jego wymiaru leksykalnego czy też semantyczno-pragmatycznego, stylistycznego i społecznego. Nieodpowiednia jest też analiza mechanizmu kongruencji morfosyntaktycznej oraz fleksyjnej nieodmienności leksemów inherentnie męskich używanych w odniesieniu do kobiet, ponieważ są to odrębne zjawiska językowe a wykorzystywanie ich do kodowania informacji o płci żeńskiej, wynikające właśnie z braku symetrii w słownictwie języka polskiego, nie może stanowić argumentu na korzyść utrzymania takiej asymetrii, również dlatego, że tego typu struktury językowe sa systemowo niegramatyczne i interpretowane jako mało naturalne w języku polskim (Laziński 2006; Latos 2018). Ponadto opinia z 2012 roku nie opiera się na współczesnych badaniach czy danych statystycznych informujących o aktualnym użyciu form żeńskich.

Z perspektywy kodyfikacji normy językowej opinia z 2012 roku pełni funkcję ochronną i po części retardacyjną (zob. Markowski 2005). Widoczne jest w niej dążenie do zakwestionowania elementów językowych ocenianych jako systemowo dopuszczalne (tj. „,wykorzystujące możliwości słowotwórcze polszczyzny”), ale niezgodne z dominującym modelem, tj. z użyciem 
nieodmiennej formy męskiej („ugruntowanym zwyczajami”). Mogą one, co najwyżej, być uznane za formy dopuszczalne tylko w niższych warstwach czy odmianach języka standardowego (tj. w języku potocznym). Stanowisko, ograniczone głównie do krytyki nowych lub niestandardowych form feminatywnych bez wskazania rozstrzygnięć kodyfikacyjnych, może być scharakteryzowane jako postawa sytuująca się między podejściem liberalnym (tj. rezygnacja z kodyfikacji normy) a zdecentralizowanym (tj. wybór rozstrzygnięć normatywnych proponowanych przez ekspertów w zależności od potrzeby użytkownika języka) (zob. Puzynina 1998).

Stanowisko Rady w sprawie feminatywów ogłoszone w 2019 roku jest diametralnie odmienne od opinii wyrażonej przez specjalistów do spraw języka niespełna osiem lat wcześniej. W odróżnieniu od stanowiska z roku 2012, w nowej opinii Rada eksplicytnie zachęca do symetrycznego używania form osobowych w języku polskim, aczkolwiek dystansuje się od pozycji normatywnych narzucających określone wzorce językowe, by zaproponować rozwiązanie bardziej wyważone, które jest otwarte na zachodzące w języku zmiany, ale definitywnie uwarunkowane wyborami jego użytkowników, które podyktowane są również ich indywidualnymi preferencjami i gustami językowymi.

Należy docenić fakt, iż w nowym stanowisku wyraźnie podkreślana jest wieloaspektowość zagadnienia feminatywów, które mimo to rozstrzygane jest głównie przez społeczny pryzmat komunikacji międzyludzkiej, a nie w jej wymiarze wewnętrznojęzykowym. Na zmianę stanowiska poza opinią publiczną wpłynęły prawdopodobnie liczne prace językoznawcze i badania naukowe poświęcone zagadnieniu feminatywów i nazw osobowych w języku polskim, które powstały w ostatnich latach.

Postulując rozstrzygnięcie o charakterze poprawnościowym, Rada nie narzuca jednolitego wzorca. W stanowisku proponowane są działania modelujące i upowszechniające nowe użycia, które nie stanowią jeszcze skodyfikowanego modelu językowego, a w dłuższej perspektywie czasowej, także działania wspierające stabilizację wzorca (zob. Markowski 2005). Opinia sytuuje się pomiędzy poradnictwem zdecentralizowanym a postawą umiarkowanie centralistyczną (tj. dążeniem do formułowania jednolitych rozstrzygnięć normatywnych, zob. Puzynina 1998).

Trudne, jeśli nie wręcz niemożliwe, jest umotywowanie rozbieżności występujących w dwóch opiniach Rady procesami stricte językowymi. Zmiana stanowiska w kwestii feminatywów wyraźnie pokazuje, że problematyka użycia żeńskich form osobowych, a w szerszym ujęciu - dynamika funkcjo- 
nowania słownictwa w obszarze nazw osobowych, których desygnatami są istoty ludzkie, jest nierozerwalnie związana $\mathrm{z}$ wymiarem społeczno-ideologicznym, kulturowym, a nawet emocjonalnym języka. To właśnie ta specyfika nazw osobowych powoduje, iz debata nad ich funkcjonowaniem w języku i w społeczeństwie trwa od lat i nie traci na swojej aktualności. Jest przecież debatą nad językowym samookreśleniem i relacjonowaniem się osób i użytkowników wspólnego kodu językowego.

Warto zauważyć, że historia języków naturalnych i norm językowych, definiowalnych jako spis wzorcowych, poprawnych lub zgodnych z przyjętym zwyczajem, realizacji językowych, w tym norm promujących maskulinizację leksykalną języka systemowo predysponowanego do sygnalizowania różnicy płciowej, pokazuje, że język był i jest regulowany społecznie. Tego typu regulacje sa nieodzownie wpisane w funkcję tradycyjnych gramatyk normatywnych lub słowników, w których decyzje leksykograficzne często podyktowane są nie tylko kwestiami technicznymi, lecz także specyficznymi normami językowymi czy też preferencjami teoretycznymi autorów (Krysiak 2016), odzwierciedlającymi nierzadko tendencje społeczno-kulturowe determinujące uzus językowy ${ }^{16}$.

W językoznawstwie współczesnym akcentuje się potrzebę nienormatywnego opisu języka. Systematyczna obserwacja i analiza realizacji językowych w określonym kontekście społeczno-historycznym pozwala na wyróżnienie tendencji i zmian zachodzących w komunikacji werbalnej danej grupy językowej. Rejestrowanie i modelowanie nowych użyć językowych nie musi być identyfikowane z odgórnym narzucaniem normy kodyfikacyjnej. Działania takie moga wspierać i przyspieszać proces zmian językowych wynikających $\mathrm{z}$ istotnych przemian w rzeczywistości pozajęzykowej.

Zarysowana ewolucja myśli normatywno-doradczej Rady Języka Polskiego w sprawie żeńskich form osobowych zbliża polską instytucję publiczną do pozycji zajętych w tej kwestii przez inne europejskie ośrodki i instytuty kulturalno-językowe pełniące funkcje opiniodawczo-doradcze w sprawach języka narodowego (np. włoska Accademia della Crusca, francuska Académie

$16 \mathrm{~W}$ Wielkim stowniku jezyke polskiego (https://wsjp.pl) WSJP pod red. Piotra Żmigrodzkiego nierzadko rejestrowane są tylko i wyłącznie męskie formy osobowe i nie są podawane informacje czy wskazówki na temat językowego wyrażania płci żeńskiej, zob. np. jezyłkoznawca, psycholog, kibic. Ponadto, słownik odnotowuje tylko niektóre nowe feminatywy, np. żołnierka, pilotka, a ignoruje inne, np. architetka, dla których jako jedyne rozwiązanie wskazuje się formę męską, w składni męskiej lub żeńskiej (w drugim przypadku forma staje się fleksyjnie nieodmienna). 
française czy hiszpański Instituto Cervantes) oraz jest spójna z polityką równouprawnienia kobiet i mężczyzn oraz równości płci przyjętą i promowaną przez międzynarodowe instytucje polityczne, np. Unesco (1987) czy Unię Europejską (1990).

Z perspektywy użytkownika języka polskiego zmiana stanowiska Rady Języka Polskiego jest faktem w pełni pozytywnym. Przedstawienie zjawisk i zmian leksykalnych w sposób neutralny (nieideologiczny) i w oparciu o zaktualizowane dane frekwencyjne pomaga w zrozumieniu złożoności problematyki nazw osobowych. W opinii zachęca się do symetrycznego używania feminatywów, nie ignorując rozwiązań zakotwiczonych w uzusie współczesnej polszczyzny. Wybór uwarunkowany jest potrzebami i preferencjami użytkowników języka. Stanowisko promujące 'nowe' i jednocześnie uznające 'tradycyjne' środki językowe jest ważnym kompromisem, jeśli weźmiemy pod uwagę asymetrię leksykalną i heterogeniczność mechanizmów słowotwórczych w obszarze polskich nazw osobowych oraz brak konsekwencji w doborze wykładników płci żeńskiej stosowanych przez użytkowników języka polskiego.

Z perspektywy językoznawcy zajmującego się problematyką feminatywów zmiana stanowiska w sprawie feminatywów jest niezwykle ważnym elementem kreowania klimatu ideologicznie neutralnego, który sprzyja prowadzeniu rzetelnych i wieloaspektowych badań naukowych nad niezwykle ciekawym, aczkolwiek złożonym, zjawiskiem językowym dotyczącym aktualnego i przyszłego użycia form osobowych w języku polskim.

\section{Bibliografia}

Bralczyk J., 2014, Premiera, megiera, hetera. Prof. Bralczyk: ju்̇ tatwiej być ministra, https://www.tvp.info/16784222/premiera-megiera-hetera-prof-bralczyk-juz-latwiej-byc-ministra [dostęp: 21.02.2020].

Croft W., 2003, Typology and Universals, Cambridge.

Dahl, Ö., 2000, Animacy and the notion of semantic gender, w: Unterberck B., Rissanen M., red., Gender in Grammar and Cognition, Berlin \& New York.

Doroszewski W., 1954, Z zagadnień leksykografii jezyka polskiego, Warszawa.

Grochowska M., Wierzbicka A., 2015, Produktywne typy stowotwórcz̧e nazw żeńskich we wspótczesnej polszczyźnie, „Acta Universitatis Lodziensis. Folia Linguistica”, 49.

Klemensiewicz Z., 1957, Tytuly i nazwy zawodowe kobiet w swietle teorii i praktyki, ,Język Polski”, 37.

Komander P., 2017, Żenskie nazwy zawodów, czyli poślica i profesora, http:/ / secundum.pl/zenskienazwy-zawodow-czyli-kierownica-albo-elektryczka [dostęp: 10.012.2019].

Krawczyk S., 2019, Gender niszczyt nasz jezyle juz w XVI wieku, https://magazynkontakt. $\mathrm{pl}$ /gender-niszczyl-nasz-jezyk-juz-w-xvi-wieku [dostęp 10.04.2020]. 
Krysiak P., 2016, Feminatywa w polskiej tradycji leksykograficænej, „Rozprawy Komisji Językowej”, XLII.

Kubiszyn-Mędrala Z., 2007, Żenskie nazuy tytutów i zawodów w stownikach wspótczesnego jezylka polskiego, „LingVaria”, 1(3).

Latos A., 2018, Agentivi femminili in italiano e polacco: ai confini fra società, uso e sistema linguistico, w: Lukaszewicz J., Słapek D., a cura di, Confini e zone di frontiera negli/degli studi italiani, Alessandria.

Latos A., 2019, Verso una tipologia di esponenti linguistici del genere femminile. L'italiano e il polacco a confronto, w: Krapova I. et al., a cura di, Atti del VII Incontro di Linguistica Slava, Venezia.

Lehmann W.P., 1993, La linguistica indoeuropea, Bologna.

Lepschy G., 1998, Lingua e sessismo, w: Lepschy G., a cura di, Nuovi saggi di linguistica italiana, Bologna.

Luraghi S., 2006, La nascita del genere femminile in indoeuropeo, w: Luraghi S., Olita A., a cura di, Linguaggio e genere. Grammatica e usi, Roma.

Łaziński M., 2006, O panach i paniach. Polskie rzeczowniki tytularne i ich asymetria rodzajowo-płciowa, Warszawa.

Majka-Rostek, D., Banaszak E., Czajkowski P., red., 2015, Genderowe filtry. Różnorodność doswiadczenia i percepcji płci w przestrzeni publicznej i prywatnej, Wrocław.

Małocha-Krupa A., red., 2015, Stownik nazw żenskich polsz̨zyzny, Wrocław.

Markowski A., 2005, Kultura jezyka polskiego. Teoria. Zagadnienia leksykalne, Warszawa.

Markowski A., Jadacka H., red., 1999, Nowy stownik poprawnej polszçyzny, Warszawa.

Meillet A., 1908, Introduction à l'étude comparative des langues indo-européennes, Paris.

Miodek J., 2010, Socjolożka cay (pani) socjolog?, http://www.gazetawroclawska.pl/arty kul/311691,jan-miodek-socjolozka-czy-pani-socjolog,id,t.html [dostęp: 15.03.2019].

Nowowsad-Bakalarczyk M., 2009, Pté́ a rodzaj gramatyczny we wspótczesnej polsz̧zyźnie, Lublin.

Ostromęcka-Frączak B., 2016, Dokad żmierza polsz̨czyzua?, „Rozprawy Komisji Językowej LTN”, t. LXII.

Puzynina J., 1998, Problem kodyfikacji normy jesyka polskiego, http://www.rjp.pan.pl/in dex.php?option $=$ com_content\&view $=$ article\&id $=95$ :problem-kodyfikacji-normy-jzyka-pol skiego\&catid $=45 \&$ Itemid $=55$ [dostęp: 10.04 .2020$]$.

Sasse H.-J., 1993, Syntactic categories and subcategories, w: Jacobs J. et al., eds., Syntax: An international handbook of contemporary research, Berlin.

Scheller-Boltz D., 2017, Ideologia płci w jednojezycznych stownikach jezykea polskiego, „Postscriptum Polonistyczne", nr 19 (1).

Sosnowski W., Satoła-Staśkowiak J., 2019, O problematyce kobiecej na płasžçyźnie jezyłkowej w kontekście ragadnienia równych szans w Polsce, Rosji i Bułgarii, „Socjolingwistyka”, XXXIII.

Tabakowska E., 2001, Linguistic expression of perceptual relationships: Iconicity as a principle of text organization (A case study), Kraków.

Wiśniewiecka-Brückner K., 2016, Zmiana - ewolucja - rewolucja. O jezyku, normie i metodach na prayketadzie rekcji dopetniaczowej czasownike polskiego, „Rozprawy Komisji Językowej LTN”, t. LXII.

Żmigrodzki P., 2015, O btędach (nie tylko jezykowych) stylu odbioru dzieła leksykograficznego i perspektywach polskiej normatywistyki jezy)kowej (w odpowiedzi Pitorowi Zbrógowi), „Język Polski”, z. 3. 
Agnieszka Latos - dr, Katedra Italianistyki i Iberystyki, Wydział Nauk Humanistycznych i Społecznych, Uniwersytet Humanistycznospołeczny SWPS, Warszawa, Polska.

Jej główne zainteresowania naukowe to: językoznawstwo teoretyczne i kontrastywne, językowe wyrażanie pojęć i złożonych relacji semantycznych, rozwój semantyczny wyrazów, akwizycja gramatyki języka drugiego L2. Autorka monografii Factual Concessive Connectors. A contrastive analysis in Italian and Polish (Munich, 2006) oraz szeregu artykułów poświęconych zagadnieniom językoznawczym w obszarach zainteresowań naukowych. W latach 2012-2017 współpracowniczka międzynarodowego projektu naukowego VILLA ANR-ORA, oraz jego kontynuacji VILLA follow-up GDRI SLAT.

Kontakt: alatos@swps.edu.pl 